\title{
Cyber Arkeologi Dalam Komunikasi Arkeologi Kepada Publik Sebagai Sarana Pelestarian Cagar Budaya
}

\author{
Fauzan Amril \\ Program Studi Magister Arkeologi, Fakultas Ilmu Pengetahuan Budaya, Universitas Indonesia \\ Email : fauzanamril79@gmail.com
}

\begin{abstract}
Abstrak: Masalah yang dibahas dalam tulisan ini adalah mengenai penyebaran informasi mengenai arkeologi yang masih sangat terbatas. Untuk itu diperlukan saluran-saluran atau media-media komunikasi yang dapat menjangkau kepada seluas mungkin lapisan masyarakat. Dengan mempelajari bentuk-bentuk komunikasi yang telah dilakukan, dalam tulisan ini bermaksud untuk memberikan alternatif terhadap model komunikasi, dalam hal ini berupa cyber-arkeologi yaitu berkomunikasi melalui dunia maya. Penyebaran informasi atau berkomunikasi melalui dunia maya diharapkan dapat menjangkau lebih luas lagi publik yang membacanya sehingga masyarakat pun memahami tentang nilai penting yang terkandung di dalam kebudayaan yang mereka miliki, yang pada akhirnya pula dapat membawa masyarakat terlibat dalam upaya pengelolaan dan pelestariannya.
\end{abstract}

Kata Kunci: Arkeologi Publik, Komunikasi, Otentisitas, Pelestarian.

\begin{abstract}
Issues discussed in this paper is on the dissemination of information about archaeology which is still very limited. It required channels or communication media to reach out to the broadest possible layers of society. By studying the forms of communication that have been made, this paper intends to provide an alternative to the model of communication, in this case is cyber-archeology that communicate through cyberspace. Dissemination of information or communicating through the virtual world is expected to reach a broader public who read it, so that the public understands about important values embodied in their culture, which eventually brought the community involved in the management and preservation.
\end{abstract}

Keywords: Public Archaeology, Communication, Authenticity, Preservation.

\section{Pendahuluan}

\section{A. Latar Belakang}

Arkeologi adalah ilmu yang mempelajari tentang masa lalu melalui budaya materinya. Arkeologi mencoba untuk memahami bentuk dari masa lalu, melalui analisis bentuk arkeolog mencoba memahami pola distribusi dari tinggalan masyarakat masa lalu pada ruang dan waktu. Dari bentuk dan hubungannya dengan tinggalan masa lalu arkeolog dapat menentukan fungsi dari benda tersebut, yang kemudian dapat merekonstruksi perilaku manusia masa lalu. Selain itu arkeolog juga akan memahami proses budaya melalui bukti-bukti arkeologi, menjawab pertanyaan bagaimana dan mengapa kebudayaan berubah melalui materi budayanya (Sharer dan Ashmore, 1979: 12).

Benda tinggalan masa lalu tersebut merupakan data arkeologi yang melaluinya para arkeolog mencoba memahami masa lalu. Bentuk dari data arkeologi antara lain berupa artefak, fitur, dan ekofak. Artefak adalah benda yang dapat dipindahkan yang bentuknya secara keseluruhan atau sebagian diubah oleh aktivitas manusia, fitur adalah artefak yang tidak dapat dipindahkan (tidak dapat diangkat dan tidak dapat dilepas dari konteksnya) tanpa mengubah atau merusak bentuk aslinya, dan ekofak adalah benda yang bukan merupakan artefak atau berupa material tetapi memiliki relevansi dengan budaya, walaupun bukan hasil aktivitas manusia secara langsung ekofak juga memberikan informasi penting mengenai tingkah laku manusia masa lalu (Sharer dan Ashmore, 1979: 70-72). Selain ketiga bentuk data arkeologi tersebut terdapat pula data arkeologi yang disebut dengan situs, menurut Undang-undang No 11 Tahun 2010 tentang Cagar Budaya, situs adalah lokasi yang mengandung benda cagar budaya, bangunan cagar budaya, dan/ atau struktur cagar budaya sebagai hasil kegiatan manusia atau bukti kejadian pada masa lalu (UU No 11 Tahun 2010, Pasal 1 Ayat (5)). Di dalam undang-undang ini yang dimaksud dengan benda cagar budaya dapat disamakan dengan artefak sedangkan bangunan dan struktur cagar budaya merupakan fitur.

Berbagai istilah dan definisi yang disebutkan di atas merupakan istilah dan definisi serta objek yang menjadi keseharian bagi para arkeolog atau orangorang yang berkecimpung dibidang penelitian maupun 
pelestarian warisan budaya. Istilah dan definisi serta objek yang mungkin belum dikenal oleh masyarakat pada umumnya. Para arkeolog akan dengan mudah mengidentifikasi sebuah benda digolongkan ke dalam artefak, fitur, ekofak, atau situs. Namun hal ini tidak mudah untuk diketahui oleh orang awam karena pengetahuan tentang hal tersebut bisa dikatakan belum menyentuh kepada sebagian besar masyarakat, sehingga menyebabkan kurangnya kepedulian masyarakat terhadap tinggalan budayanya dalam hal ini yang berupa kebendaan.

Undang-undang No 11 Tahun 2010 tentang Cagar Budayapada Pasal 1 ayat (21) memberikan penekanan kepada memajukan kebudayaan nasional untuk sebesarbesarnya kemakmuran rakyat, hal ini menunjukkan bahwa ada kepentingan untuk memakmurkan masyarakat melalui kebudayaan. Seorang arkeolog juga dituntut untuk mengabdikan diri pada ilmu dan pengetahuan arkeologi dalam rangka pengembangan ilmu pengetahuan dan pemanfaatan bagi kehidupan masyarakat, sebagaimana yang tertera dalam mukadimah AD/ART IAAI yang lengkapnya sebagai berikut:

"sebagai warga negara yang menyadari pentingnya warisan budaya nasional, dalam rangka pengembangan ilmu pengetabuan, dan pemanfaatan bagi kehidupan masyarakat serta untuk memperkukuh jadidiri bangsa, maka abli arkeologi Indonesia mengabdikan diri pada ilmu dan pengetahuan arkeologi dengan pemikiran, pendekatan, dan cara-cara yang positif ilmiah serta dengan penuh tanggung jawab kepada nusa dan bangsa." (dalam Supardi, 2012: 126)

Seorang arkeolog memiliki tanggungjawab untuk menyampaikan hasil penelitiannya kepada masyarakat sebab biaya penelitian yang dilakukan oleh arkeolog berasal dari rakyat sehingga hasil penelitian tersebut sudah semetinya dapat memberikan manfaat bagi masyarakat (Magetsari, 2012: 117). Jadi tanggung jawab seorang akeolog tidak berhenti pada menyampaikan saja tetapi hingga dapat memberikan manfaat pada masyarakat serta dapat mengajak masyarakat untuk terlibat dalam upaya pelestariannya.

Berkaitan dengan memberikan manfaat kepada masyarakat, yang perlu menjadi perhatian adalah bagaimana membuat masyarakat tahu terlebih dahulu berkaitan dengan hasil penelitian arkeologi maupun objek yang menjadi perhatian arkeologi, dalam hal ini kebudayaan dari benda-benda tinggalan masa lalu. Berbicara mengenai menyampaikan informasi kepada pihak lain maka akan berkaitan dengan permasalahan komunikasi yaitu proses pengiriman pesan dari satu pihak ke pihak lain (Widodo, 2012: 34).

Melalui komunikasi maka berbagai informasi berkaitan dengan ke-arkeologi-an baik penelitian maupun pelestariannya dapat disampaikan kepada masyarakat. Komunikasi memiliki tujuan memastikan adanya pemahaman terhadap informasi atau pesan yang disampaikan, membangun pengertian atau pemahaman, serta memberikan motivasi untuk melakukan berdasarkan informasi tersebut (Pace, 2002 dalam Widodo, 2012 : 35). Pesan yang disampaikan melalui komunikasi diharapkan dapat diterima dengan pemahaman yang baik oleh penerimanya, dan dari pemahaman tersebut akan mendorong untuk melakukan tindakan-tindakan berdasarkan informasi yang telah dipahami termasuk berpartisipasi dalam upaya pelestarian cagar budaya.

Berdasarkan beberapa hal yang dikemukakan di atas dapat diketahui bahwa upaya pelestarian dapat berjalan dengan baik apabila pemahaman mengenai cagar budaya serta pelestariannya dimiliki pula oleh masyarakat, pemberian pemahaman kepada masyarakat dilakukan melalui proses komunikasi yang baik. Oleh karena itu permasalahan yang diajukan dalam tulisan ini adalah bagaimana bentuk komunikasi yang efektif dalam pemberian informasi kepada masyarakat agar masyarakat dapat memahami tentang cagar budaya dan dapat terlibat dalam upaya pelestariannya.

\section{Pembahasan}

\section{A. Komunikasi Melalui Dunia Maya}

Manusia tidak akan lepas dari berkomunikasi, komunikasi sudah menjadi kebutuhan bagi manusia sebab melalui komunikasi manusia akan saling berhubungan satu sama lain. Harold D. Lasswell dalam Canagara (2011: 2-3) menyebutkan ada tiga fungsi yang menyebabkan manusia memerlukan komunikasi yaitu manusia memiliki keinginan mengontrol lingkungannya, manusia berupaya untuk beradaptasi dengan lingkungannya dan manusia berupaya melakukan transformasi warisan sosialisasinya. Melalui komunikasi manusia dapat memahami segala sesuatu dengan proses belajar, sehingga manusia dapat mengontrol lingkungannya dari pemahaman yang 
diperoleh dengan belajar dan melalui berkomunikasi. Manusia perlu menyesuaikan dengan lingkungannya, dalam hal untuk mengontrol lingkungan tersebut maka manusia perlu beradaptasi dengan lingkungan, proses adaptasi dipahami pula melalui proses komunikasi. Pada akhirnya manusia akan mempertahankan eksistensinya dengan cara mentransformasi warisan sosialisasinya, yang dalam hal ini dapat terlaksana karena adanya komunikasi dari orangtua kepada anaknya atau sebuah bentuk komunikasi yang terjadi pada proses belajar mengajar di sekolah atau dalam berbagai bentuk komunikasi.

Dalam beberapa pengertian komunikasi adalah proses mengalihkan ide atau informasi dari sumber informasi kepada seorang atau beberapa orang dengan tujuan mengubah tingkah laku mereka (Everett M. Rogers dalam Cangara, 2011: 20). Dari pengertian ini berarti ada maksud dari sebuah komunikasi untuk merubah tingkah laku, jika pada awalnya seseorang tidak memahami tentang arkeologi sehingga ada sikap ketidak pedulian terhadap hal-hal yang berkaitan dengan arkeologi, setelah ada proses komunikasi diharapkan seseorang atau sekelompok orang akan memahami atau terjadi perubahan tingkah laku pada seseorang atau sekelompok orang tersebut terhadap berbagai hal yang berkaitan dengan arkeologi, baik yang berkaitan dengan hasil penelitiannya maupun berkaitan dengan aktivitas pelestariannya.

Agar pesan yang diharapkan sampai maka diperlukan komunikasi yang efektif, komunikasi yang efektif dapat terjadi jika terdapat pertukaran pengalaman yang sama pada dua pihak yang melakukan komunikasi, walaupun tidak ada penerimaan yang seutuhnya antara dua pihak yang melakukan komunikasi tetapi komunikasi tersebut dapat dikatakan efektif ketika ada banyak hal yang dapat dipahami bersama. Menurut Aristoteles terjadinya komunikasi disebabkan oleh tiga unsur yaitu siapa yang berbicara, apa yang dibicarakan, dan siapa yang mendengar. David K. Berlo memformulasikan komunikasi dengan istilah SMCR yaitu singkatan dari Source (pengirim), Message (pesan), Channel (saluran/ media), dan Receiver (penerima). Belakangan ini unsur lingkungan menjadi salah satu unsur dalam komunikasi karena faktor lingkungan dianggap sebagai yang dapat mempengaruhi jalannya proses komunikasi (Cangara, 2011: 21-27).
Pengirim menyampaikan pesannya melalui suatu saluran atau media agar sampai kepada penerima. Media merupakan sarana yang digunakan untuk menyampaikan pesan kepada penerima pesan. Media terdiri dari empat macam, pertama adalah media antarpribadi yaitu media yang digunakan dalam melakukan komunikasi dalam hubungan perorangan, contohnya adalah pengiriman pesan melalui seorang utusan, surat, dan komunikasi antarpribadi melalui telepon. Kedua adalah media kelompok yaitu komunikasi yang meibatkan suatu kelompok dalam jumlah tertentu, komunikasi dengan menggunakan media kelompok terjadi pada sebuah rapat, seminar, dan konferensi; dalam hal ini komunikasi dengan media kelompok dapat dilakukan berupa sosialisasi mengenai cagar budaya dalam bentuk seminar. Ketiga, media publik yaitu media komunikasi yang digunakan terhadap penerima pesan dalam jumlah yang lebih besar dari kelompok yaitu lebih dari 200 orang, bentuknya dapat berupa tabligh akbar yang dilakukan oleh ulama-ulama dalam menyiarkan dakwahnya; media ini jarang dilakukan dalam rangka menyampaikan informasi berkaitan dengan arkeologi. Keempat adalah media massa yaitu media komunikasi yang dilakukan terhadap penerima pesan yang tidak diketahui keberadaannya, media massa merupakan alat yang mentransfer pesan dari sumbernya dengan menggunakan alat komunikasi berupa surat kabar, radio, televisi, dan komputer dengan internetnya. Melalui media massa informasi dapat tersebar tanpa dihalangi oleh jarak dan waktu, pesan yang disampaikan dapat diterima kapan saja oleh siapa saja dan di mana saja (Cangara, 2011: 125154).

Dengan munculnya internet media antarpribadi, media kelompok maupun media publik dapat dilakukan dalam satu media yaitu media massa. Media antarpribadi yang biasa dilakukan melalui surat menyurat dapat dilakukan lewat internet dengan electronic mail atau yang dikenal dengan e-mail, rapat-rapat yang biasa dilakukan secara tatap muka berkumpul dalam satu ruangan, melalui internet dapat dilakukan secara jarak jauh dengan teknologi skype-nya, dan lain sebagainya bahwa media massa dalam bentuk virtual telah menjadikan komunikasi lebih mudah dan lebih efektif.

Aktivitas manusia diberbagai penjuru dunia dapat diketahui dan disaksikan oleh manusia lain di penjuru dunia lainnya melalui internet dengan dunia 
virtualnya. Tentang hal ini kita mengenal seorang filsuf asal Prancis yang terkenal dengan konsep simulacra, byperreality, sign, virtual, dan lain-lain, yaitu Jean Baudrillard. Menurut Baudrillard simulasi merupakan realitas secara menyeluruh yang menggabungkan dimensi simulasihiperrealisme. Konsep Baudrillard tentang byperreality sangat mempengaruhi pada kajian-kajian komunikasi, informasi, sosial, politik, dan lain-lain, menurutnya realitas lama sudah mati dengan munculnya realitas baru yang disebut dengan hiperrealitas tadi (Lubis, 2014: 170171).

Melalui bukunya yang berjudul Simulation dan selanjutnya dikembangkan pada buku yang terbit kemudian dengan judul Simulacra and Simulacrum, Baudrillard mencoba menjelaskan bahwa simulasi merupakan realitas yang dibentuk oleh berbagai hubungan tanda dan kode secara acak tanpa referensi yang jelas, era di mana keaslian atau realitas telah lenyap digantikan dengan realitas virtual. Yang nyata telah digantikan dengan yang tidak nyata atau byperreal atau realitas virtual. Turkle menyatakan bahwa realitas virtual lebih menggambarkan kehidupan yang nyata ketimbang kenyataan itu sendiri, lebih benar ketimbang kebenaran itu sendiri (Lubis, 2014 : 180-189). Simulasi akan memberikan kesan yang lebih daripada aslinya, sebuah iklan akan menyampaikan kebaikan-kebaikan dari produk dengan membuat simulasi seolah-oleh sebuah produk akan memberikan efek yang cepat terhadap penggunanya. Misalnya iklan obat, di televisi ditampilkan sesaat setelah minum obat maka orang tersebut akan langsung sembuh, padahal kenyataannya diperlukan proses untuk penyembuhan.

Dalam dunia arkeologi simulasi diperlukan untuk mentransfer pengetahuan kepada masyarakat, hal ini berkaitan dengan tanggungjawab seorang arkeolog yang di dalam undang-undang diamanatkan bahwa pelestarian kebudayaan nasional untuk sebesar-besarnya memakmurkan masyarakat. Penyampaian informasi melalui internet atau dunia maya merupakan salah satu bentuk simulasi yang diungkapkan oleh Baudrillard dalam Lubis (2014), yang dalam beberapa hal ditujukan untuk menampilkan tiruan lebih unggul dari aslinya. Dalam hal keperluan arkeologi, di mana informasi yang ingin disampaikan merupakan informasi yang sebenarnya maka yang diharapkan dalam kemasan media komunikasi dalam bentuk media massa melalui dunia maya atau virtual reality, maka dalam hal ini ketepatan informasi menjadi suatu yang sangat diperhatikan, sebuah tiruan harus menggambarkan sebagaimana aslinya. Komunikasi melalui dunia maya berdasarkan jenis media pada ilmu komunikasi merupakan media massa, dan media massa memanfaatkan kemajuan teknologi komputer dengan perkembangan internetnya, hal ini merupakan media yang juga digunakan dalam penyebaran informasi mengenai arkeologi sehingga pengetahuan arkeologi dapat dipahami dan diwarisi.

\section{B. Arkeologi di Dunia Maya}

Arkeologi sebagaimana telah dipaparkan di atas adalah ilmu yang mempelajari masa lalu melalui tinggalan budaya berupa material (material culture). Objek arkeologi adalah sesuatu yang unik, langka, dan tidak dapat diperbaharui oleh karena itu melestarikannya merupakan cara untuk mempertahankan keberadaannya agar dapat diambil manfaatnya. Selama ini masyarakat dapat menyaksikan benda-benda tersebut ditampilkan dimuseum-museum atau melalui media cetak berupa buku, brosur, maupun media cetak lainnya. Walaupun demikian arkeologi masih dirasakan sebagai sebuah ilmu masa lalu yang kuno, yang mungkin akan menghambat pembangunan atau modernisasi. Generasi saat ini adalah generasi yang teknologi maupun informasi berada di genggaman, dengan bermunculannya teknologi baru di dunia informasi maka informasi dapat diakses kapan saja dan di mana saja.

Kemajuan teknologi ini mendorong arkeologi untuk dapat menyesuaikan diri dengan keadaan. Menuntut para arkeolog untuk lebih kreatif dalam menampilkan dunia arkeologi kepada khalayak ramai dalam berbagai segmentasinya. Arkeolog atau siapapun yang terlibat dalam pelestarian benda arkeologi haruslah menempatkan objek arkeologi sebagai product-knowledge, yaitu objek arkeologi merupakan pesan yang nilai informasinya perlu diidentifikasi, dengan demikian menampilkan objek arkeologi tidak hanya menampilkan bendanya saja tetapi juga pesan yang terkandung di dalamnya. Pesanpesan tersebut selanjutnya dapat membawa orang yang melihatnya kepada peristiwa yang pernah dialami oleh benda tersebut (Widodo, 2012: 36-37).

Media yang tepat dalam hal penyampaian informasi tentang akeologi adalah media massa, 
sebagaimana telah dijelaskan media massa merupakan media penyampaian pesan dari sumbernya kepada penerima sumber dengan menggunakan alat komunikasi mekanis seperti surat kabar, film, radio, televisi, dan perkembangan terakhir adalah melalui internet (Cangara, 2011:128)

Sebagaimana telah dipaparkan sebelumnya, informasi yang dikomunikasikan dengan berbagai bentuk media diharapkan dapat memberikan pengetahuan dan kesadaran kepada khalayak, oleh karena itu diperlukan alat komunikasi yang tepat, mudah diakses, dan menarik. Media berupa surat kabar adalah media yang sudah umum digunakan namun terkadang tidak semua orang menyukai dengan membaca terlebih lagi jika disuguhkan dalam teks yang panjang. Media berupa film mungkin akan lebih menarik, seperti film Indiana Jones yang memang menjadi inspirasi beberapa orang untuk masuk jurusan arkeologi, tetapi film bukanlah media yang interaktif sehingga penonton tidak dapat merasakan secara langsung dari apa yang disuguhkan, penonton hanyalah menjadi penonton. Media radio merupakan alat komunikasi dengan cara mendengar, tidak ada yang bisa dilihat melalui media radio, pendengar diharapkan dapat berimajinasi mengenai hal-hal yang disampaikan melalui media radio. Terlepas dari itu semua, setiap media ini memiliki tujuan yang sama yaitu menyampaikan pesan atau informasi. Tujuannya mungkin dapat dicapai tetapi dalam hal interaksi dengan objek sangatlah kecil kemungkinannya untuk dicapai sehingga penerima pesan tidak dapat merasakan informasi disampaikan.

Untuk itu perlu media komunikasi yang dapat juga dirasakan oleh penerima pesan. Beberapa yang dapat dilakukan antara lain berupa simulasi 3 dimensi, menampilkan objek digital, dan yang berupa kawasan dengan cara merekonstruksinya dan membuat beberapa simulasi di beberapa lokasi pada kawasan tersebut. Dalam hal menampilkan benda koleksi ataupun penyampaian informasinya, otentisitas menjadi perhatian dalam arkeologi. Berkaitan dengan hal ini selalu menjadi perdebatan berkaitan dengan keaslian dari objek dalam menampilkannya. Objek-objek tiruan oleh Baudrillard disebut sebagai simulacra, ia adalah sebuah citra dari material sebagai representasi dari orang atau sesuatu, menurutnya juga bahwa citraan ini tidak memiliki substansi sehingga tidak menunjukkan hal yang nyata.
Hal karena Baudrillard berpendapat bahwa saat ini adalah zaman di mana keaslian sudah lenyap (Lubis, 2014 : 180).

Perdebatan berkisar pada otentisitas dan apakah objek tiruan atau objek digital dapat mewakili dari objek yang asli. Dan apakah keterwakilan objek asli dengan objek tiruan atau objek digital dapat menyampaikan informasi atau pengetahuan yang terdapat pada objek asli. Berkaitan dengan hal ini Fiona Cameron (2007) membuat kajian bagaimana sebuah replika ditampilkan untuk mewakili objek aslinya dalam sebuah museum. Ia mencoba mengungkapkan dari dua sudut pandang, yaitu sudut pandang tradisional yang menilai bahwa objek asli tidak dapat digantikan dengan replika dalam hal ini terdapat kekhawatiran oleh penganut paham tradisional berkaitan dengan makna yang hilang pada sebuah objek. Sedangkan sudut pandang kedua yaitu sudut padang postmodern yang dalam hal ini diwakili oleh Baudrillard, memandang bahwa objek asli dapat diwakilkan dengan tiruan, sebab intinya adalah apa yang ingin disampaikan bukan bagaimana menyampaikan. Menurut Baudrillard reproduksi virtual merupakan analog yang sempurna dan memiliki arti yang sama dengan objek aslinya.

Sementara pihak yang menyatakan bahwa objek asli tidak dapat digantikan dengan bentuk virtual atau tiruan berpandangan bahwa objek adalah sebuah gagasan yang padanya dapat dikomunikasikan secara sempurna dengan cara menampilkan apa adanya objek tersebut, sebab tanpa objek asli, objek virtual atau tiruan tidak memiliki makna, roh dan referensi (Cameron, 2007: 53). Dalam kasus yang lain terdapat istilah authentic reproductionyang disematkan untuk sebuah situs bersejarah di New Salem. Situs ini merupakan tempat di mana Abraham Lincoln tinggal pada masa remajanya. Situs ini menggambarkan bagaimana perjuangan Lincoln hingga akhirnya menjadi presiden Amerika, dan sejarah Lincoln adalah sejarah Amerika (Bruner, 2007: 301-302).

Dalam hal ini yang dimaksud dengan reproduksi otentik berkaitan dengan New Salem adalah ingin mereproduksi apa yang pernah ada di New Salem pada tahun 1830 dan menjadikannya otentik sebagaimana yang ada pada tahun tersebut. Jadi yang dimaksud dengan reproduksi otentik di sini adalah otentik seperti pada saat tahun 1830. Dan pengertian otentik di sini dapat dibedakan menjadi beberapa pengertian, pertama kemiripan (versimility) dalam pengertian ini objek yang 
ditampilkan memiliki kemiripan dengan objek yang pernah ada pada tahun 1830, kedua keaslian (genuineness) maksudnya adalah menampilkan keaslian secara substansi pada New Salem, ketiga orisinil (original) dalam pengertian ini memang memunculkan objek yang asli, dengan beberapa objek yang masih asli di New Salem, dan keempat adalah otoritas (authority) yaitu New Salem dinilai otentik atas dasar penetapan oleh otoritas (Bruner, 2007: 302-303).

Kembali kepada permasalahan, di dalam Undang-Undang Dasar RI Tahun 1945 dalam Pasal 28C ayat (1) disebutkan: "Setiap orang berhak mengembangkan diri melalui pemenuhan kebutuhan dasarnya, berhak mendapat pendidikan dan memperoleh manfaat dari ilmu pengetahuan dan teknologi, seni dan budaya, demi meningkatkan kualitas bidupnya dan demi kesejahteraan umat manusia." Jelas dalam pasal ini disebutkan bahwa setiap orang di dalam negara kesatuan Republik Indonesia memiliki hak untuk mengembangkan dirinya, salah satunya yang diperoleh dari pemanfaatan seni dan budaya, dalam hal ini budaya dikaitkan dengan arkeologi atau tinggalan purbakalanya. Dengan informasi yang diperoleh diharapkan masyarakat dapat mengetahui tentang kebudayaannya, informasi ini disampaikan atau dikomunikasikan melalui berbagai media sebagaimana sudah dipaparkan sebelumnya.

Otentisitas yang diperdebatkan akan menjadi prioritas kedua ketika kepentingan untuk mengkomunikasikan informasi adalah tujuan utamanya, agar komunikasi menjadi efektif maka media massa melalui media internet merupakan media yang cukup efektif. Transfer pengetahuan melalui media internet yang di dalamnya juga mencakup foto digital merupakan media yang mudah diakses oleh masyarakat, sehingga dapat menjangkau kepada banyak orang dan memproduksi serta menyebarkan informasi tentang arkeologi, media internet juga dapat disajikan secara interaktif walaupun untuk ini dibutuhkan biaya yang lebih besar, seperti yang sudah dilakukan oleh situs Warisan Dunia di Lascaux yang menyajikan website interaktif sehingga pengunjung dapat mengekplorasi secara virtual (Grant, 2008: 372 376).

Selain persebarannya yang lebih luas, pemanfaatan media massa berupa internet juga dapat memberikan dampak positif dalam hal perawatan objek aslinya. Sebab objek tiruan dalam bentuk virtual menggantikan posisi objek asli, sehingga objek asli tetap berada pada tempatnya dan tidak terganggu oleh aktivitas perpindahan, hal ini akan mengurangi dampak kerusakan pada objek mengingat benda arkeologi atau koleksi museum memiliki karakter yang rapuh dan tidak dapat diperbaharui (Sektiadi, 2008: 522). Dalam hal ini penggunaan objek virtual merupakan salah satu cara mengkonservasi koleksi selain sebagai media informasi.

Walaupun demikian, objek asli merupakan bukti sejarah yang tidak bisa digantikan. Sebuah replika, bentuk digital, ataupun simulasi hanyalah bentuk komunikasi yang mempermudah tersebarnya informasi. Reproduksi suatu objek dimaksudkan untuk penyebaran kebudayaan melalui media-media baru, selain itu reproduksi melalui fotografi akan tercipta hubungan yang lebih tajam antara media dengan objeknya, dengan demikian objek digital membawa objek sejarah dan maksud dari pembuatnya kepada masyarakat di masa sekarang (Cameron, 2007: 55).

Nilai positif yang dimiliki oleh penyebaran informasi melalui internet atau cyberspace menjadikannya media yang perlu terus dikembangkan dengan tidak mengurangi nilai penting dari objek aslinya. Pengembangannya dengan memperhatikan juga sasaran dari penerima pesan tersebut, sebab penerimaan dari siswa SD akan berbeda dengan mahasiswa di universitas, sasaran yang berbeda juga akan membedakan model dari penyampaiannya. Untuk siswa SD mungkin akan lebih menarik disampaikan dalam bentuk games atau kartun yang disuguhkan secara interaktif, sedangkan untuk mahasiswa tentunya dapat disajikan dengan cara yang lebih serius.

\section{Penutup}

Kemajuan teknologi informasi menjadikan penyebarannya menjadi lebih mudah dan jangkauannya lebih luas. Segala bidang telah menikmati kemudahan dari teknologi ini tidak terkecuali arkeologi. Kebutuhan untuk memberikan informasi kepada publik mendorong para pemberi pesan atau sumber informasi menyajikan informasi semudah mungkin dan dapat dipahami dengan baik oleh penerima pesan. Penyampaian pesan melalui internet menjadi pilihan yang harus dilalui mengingat teknologi saat ini sudah semakin maju, di mana informasi sudah berada digenggaman, sehingga dimana saja dan 
kapan saja oleh siapa saja informasi itu dapat diakses.

Adalah tangung jawab sosial seorang arkeolog untuk memberikan informasi tersebut sebagai bentuk kontribusi arkeologi dalam membangun jatidiri dan karakter bangsa sehingga arkeologi dapat memasyarakat. Dengan demikian tujuan dari komunikasi ini juga dapat tercapai yaitu menyadarkan masyarakat atas apa yang telah disampaikan melalui proses komunikasi itu. Kesadaran masyarakat yang terbentuk melalui proses komunikasi dalam penyampaian informasi akan membentuk masyarakat yang peduli terhadap warisan budayanya, kepedulian yang akan membawa masyarakat pada peran sertanya dalam melestarikan, menginternalisasikan dalam diri dan kemudian dapat menyampaikannya kepada orang lain.

Komunikasi melalui cyber pada akhirnya akan membentuk cyber culture dalam dunia arkeologi. Ini adalah manfaat dari kemajuan teknologi yang memberikan

\section{DAFTAR PUSTAKA}

Bruner, Edward M. 2007. "Abraham Lincoln as Authentic Reproduction: A Critique of Postmodernism" dalam Simon J. Knell (Ed.) Museum in the Material World. Oxon: Routledge. Hal. 246-252.

Cameron, Fiona. 2007. "Beyond the Cult of ReplicantMuseum and Historical Digital Objects: Traditional Concerns, New Discources" dalam Fiona Cameron dan Sarah Kenderline (Ed.) Theorizing Digital Cultural Heritage: A Critical Discourse. Boston: MIT Press. Hal. 49-76.

Cangara, H. Hafied. 2011. Pengantar Ilmu Komunikasi. Jakarta: PT. Raja Grafindo Persada.

Lubis, Akhyar Yusuf. 2014. Postmodernisme Teori dan Metode.

Jakarta: Rajawali Pers.

Magetsari, Noerhadi. 2012. "Tanggung Jawab Sosial Ahli Arkeologi" dalam Supratikno Rahardjo (Ed.) Arkeologi Untuk Publik. Jakarta: IAAI. Hal: 103124. dampak yang sangat besar terhadap perkembangan ilmu pengetahuan. Arkeologi yang sebelumnya hanya diketahui oleh segelintir orang, hanya berputar di lingkungan peneliti atau pelestari arkeologi saja, saat ini dapat tersebar luas melalui media digital. Namun dengan tidak meninggalkan nilai penting pada objek asli dan pentingnya menjaga keaslian dari objek asli tersebut. Menjaga keaslian dari objek merupakan upaya pelestarian yang pada akhirnya akan memperpanjang usia dari objek tersebut. Sebab pada objek asli tersebutlah terdapat informasi yang akan disampaikan kepada masyarakat. Otentisitas objek dalam hal ini pada akhirnya akan berbicara mengenai otentisitas dari informasi yang disampaikan atau disajikan pada objek virtual melalui cyber arkeologi. Oleh karena itu, mengkomunikasikan arkeologi kepada publik dalam bentuk cyber arkeologi merupakan salah satu cara untuk melestarikan warisan budaya.

Sharer, Robert.J dan Wendy Ashmore. 1979. Fundamentals of Archaeology. California: The Benjamin/ Cummings Publishing Company, Inc.

Supardi, Nunus. 2012. "Arkeologi Untuk MasyarakatMasyarakat Untuk Arkeologi (Catatan Kecil Seorang Pemerhati Untuk IAAI)." dalam Supratikno Rahardjo (ed.) .Arkeologi Untuk Publik. Jakarta: IAAI. Hal: 125-134.

Widodo, Suko. 2012. "Mengkomunikasikan Makna Arkeologi Bagi Publik Dalam Konteks Kekinian” dalam Supratikno Rahardjo (ed.) Arkeologi Untuk Publik. Jakarta: IAAI. Hal: 33-38.

\section{Peraturan}

Undang-Undang Dasar Republik Indonesia Tahun 1945

Undang-Undang Republik Indonesia No. 11 Tahun 2010 Tentang Cagar Budaya. 